\title{
Tax Avoidance - Methodology for Quantification and the Case of the Netherlands
}

\author{
Marco Kerste ${ }^{1}$, Barbara E. Baarsma ${ }^{2}$ \& Jarst Weda ${ }^{3}$ \\ ${ }^{1}$ Kerste Research and Advice, the Netherlands \\ ${ }^{2}$ Rabobank and is also professor at the faculty of Economics and Business of the University of Amsterdam, the \\ Netherlands \\ ${ }^{3}$ Dutch Authority for the Financial Markets (AFM), the Netherlands \\ Correspondence: Barbara Baarsma, University of Amsterdam, P.O. Box 15867, 1001 NJ Amsterdam, The Netherlands.
}

Received:April 6, 2019

doi:10.11114/ijlpa.v2i1.4277
Accepted: May 13, 2019

Online Published: May 20, 2019

URL: https://doi.org/10.11114/ijlpa.v2i1.4277

\begin{abstract}
The goal of this paper is to define and quantitatively measure tax avoidance. So far any rigorous assessment of financial flows related to tax avoidance that entails paying (almost) no taxes, is lacking. This prevents a proper assessment of the necessity for further regulation to fight such undesirable tax avoidance. Quantifying tax avoidance provides a sound starting point for assessing the severity of regulation - matching the expected benefits with costs - and sheds further light on the possible design of effective regulation. The paper defines tax avoidance as the legal use of tax constructions aimed at paying (almost) no taxes in the entire international financial chain. Our paper shows that in order to prevent international tax systems from being used for such double non-taxation, governments could introduce a withholding tax on outgoing interest and royalty flows to low tax jurisdictions (tax havens). If the low tax threshold is set at $15 \%$ or $10 \%$ respectively, then depending on the choice for one of the two provided definitions of 'low tax jurisdiction', we find that the combined outgoing royalty and interest flow related to tax avoidance via Dutch conduit companies was on average 9.7 or 11.9 billion euro per year in the period 2009-2013.
\end{abstract}

Keywords: BEPS, conduit, interest, royalty, tax avoidance

\section{JEL Classification Codes}

E620 Fiscal Policy

F230 Multinational Firms; International Business

F380 International Financial Policy: Financial Transactions Tax; Capital Controls

H250 Business Taxes and Subsidies including sales and value-added (VAT)

H260 Tax Evasion

\section{Introduction}

In last decade there has been an increased focus, in both the public and academic realms, on the offshore tax arrangements of multinational corporations and wealthy individuals (Henry, 2012; Kar \& Freitas, 2012; Murphy, 2012; Johansson, Bieltvedt Skeie, Sorbe, \& Menon, 2017). The issue of tax avoidance also increased in the public consciousness when austerity was implemented across Europe as response to the financial crisis of 2008 (Birks, 2017). Attention was also bolstered by a series of leaks of private documents, including the 'Panama Papers' in 2016.

It is often assumed, rightly or wrongly so, that tax avoidance is purely a question of smart company tax lawyers finding loopholes in the legislation. This is a too simple assumption, as there is also carefully considered government policy behind it. Many tax laws and regulations used as part of tax avoidance exist because governments want to avoid situations where international companies have to pay tax twice. This is an internationally accepted principle - see e.g. OECD (2013). Double taxation not only affects the companies concerned; it also has broader adverse effects. It can put multinational enterprises (MNEs) at a competitive disadvantage vis-à-vis local companies, for instance, which in turn can present a barrier to international trade. 
Companies respond to the opportunities that countries offer to avoid double taxation by setting up their international structures in a particular way: they engage in international tax planning. This in turn provides governments with incentives to further optimize their tax regime, as attractive tax legislation attracts companies, which is good for the real economy. The trouble is that the laws and regulations used to do this may also provide opportunities for multinational enterprises (MNEs) to pay no or almost no tax at all. This affects country's tax revenue, leaving governments with less money to spend on public services, or the need to increase other taxes or lower public expenditures.

In the debate on international taxation, it is important to distinguish tax evasion, tax avoidance and tax planning. International corporations use international tax planning to reduce the total amount that they have to pay in tax as a group through the geographical organization of the group's activities. This is essentially legal, based on the principle of freedom of contract. Tax evasion means avoiding paying taxes by breaking the law and is therefore illegal. Both concepts, international tax planning and tax evasion, can be characterized as 'white' and 'black' respectively, but there is also a 'grey' area: tax avoidance. There is as yet no uniform, universally accepted definition of tax avoidance in the academic literature.

In recent years the attention paid to tax avoidance has consequently been overwhelming, both in the media, the academic world and in the political arena (Janský \& Palanský, 2018). MNEs setting up constructions to reduce international tax payments - although legal - have come under public scrutiny. From 'smart business' tax avoidance has turned into something that is morally unacceptable. The primary and most practical result of this change of view has been OECD's Base Erosion and Profit Shifting (BEPS) project, which sets out the path for international regulation and activities against tax avoidance (see OECD (2015a) for an overview).

The goal of this paper is to define and quantitatively measure tax avoidance. We use the concept 'of acting against the spirit of the law' to define unwanted tax evasion. Although tax facilities and treaties are aimed at preventing double taxation; these may also be used by companies to pay no or almost no tax at all. If tax facilities or treaties are used to that end, i.e. to not pay any tax at all, or almost none, they are obviously not in tune with the spirit of the law. We therefore define tax avoidance as the legal use of constructions aimed at paying no - or almost no - tax in the entire international financial chain. So we distinguish tax practices based on the extent to which they comply with the letter as well as the spirit of the law.

Our research problem is not only how tax avoidance can be defined, but also how we can quantitatively calculate the financial flows related to tax avoidance that entails double non-taxation. Being able to calculate these flows is important if rigorous testing of the necessity for further regulation to fight tax avoidance is called for. Quantifying tax avoidance provides a sound starting point for assessing the severity of regulation - matching the expected benefits with costs - and sheds further light on the possible design of effective regulation.

There has been an impressive strand of literature on tax avoidance, especially since the introduction of the BEPS project (Gumpert, Hines \& Schnitzer, 2016; Heckemeyer \& Overesch, 2017; Spengel, Heckemeyer, Nusser, Klar \& Streif, 2016). But lack of firm-level micro-data related to actually used avoidance structures still prevents precise measurement. This paper looks at the amounts involved in tax avoidance through conduit companies based on firm-level micro-data, thereby providing a practical starting point for targeted policy design. ${ }^{1}$

A conduit company is defined as a "[c]ompany set up in connection with a tax avoidance scheme, whereby income is paid by a company to the conduit and then redistributed by that company to its shareholders as dividends, interest, royalties, etc." (OECD, 2015b). ${ }^{2}$ In practice this means that money flows from a company in one country to a conduit in another country and from the conduit to a company in yet another country, aimed at reducing total taxes paid by a MNE. We put forward a method for deducing the sums that may be involved in tax avoidance from the flows passing through conduit companies. Next, we use this methodology to calculate the flows related to tax avoidance via a specific conduit country, the Netherlands, in relation to interest and royalty flows.

We selected the Netherlands because it is an important conduit country, where the public and political discussion prompted policy changes, but the quantitative substantiation underlying these changes was unclear. In order to know what new policy is required, policy makers need to know the size of the problem. How large are the financial flows for which legal tax arrangements are used to pay no or almost no taxes? Being able to calculate these flows is important if rigorous testing

1 This paper builds on earlier work by the authors (Baarsma, Kerste \& Weda, 2014), and our methodology was also applied by Van 't Riet and Lejour (2018).

2 A conduit country is not the same as a tax haven. Whereas tax havens are mostly the final destinations of financial flows in conduit constructions, a conduit country is used as an intermediate step in order to reduce taxes en route to another country or jurisdiction. 
of the necessity for further regulation to fight tax avoidance is called for.

We add to the existing literature by providing a definition that facilitates the calculation of related flows and put forward a methodology for actually calculating them. Quantifying tax avoidance provides a sound starting point for assessing the severity of regulation - matching the expected benefits with costs - and sheds further light on the possible design of effective regulation.

The structure of this paper is as follows. Section 2 discusses the literature on defining and measuring tax avoidance. Section 3 presents our methodology to calculate flows related to tax avoidance. Using this methodology we calculate financial flows related to tax avoidance via conduit companies in the Netherlands, based on interest and royalty income in section 4. We discuss our results and the limitations of our approach in section 5. Section 6 concludes and describes the policy implications.

\section{Literature}

\subsection{Framing and Defining Tax Avoidance}

As stated in section 1 international tax planning is essentially legal, based on the principle of freedom of contract. Companies are free to organize their activities with this in mind. European Court of Justice case law endorses the principle that companies are free to organize their activities in a tax-favourable way. Tax evasion means avoiding paying taxes by breaking the law, and is therefore illegal. Evasion can range from making a mistake on a tax return to sending out false invoices. There is no international yardstick for tax evasion, as every country has different tax legislation.

The grey area in which tax avoidance resides lacks a uniform, universally accepted definition. Many times tax evasion is simply not defined or merely defined indirectly in terms of (legal) techniques to avoid taxes or shift profits to minimize tax liability. When definitions are given they vary from broad, for example "...the reduction of explicit taxes" (Hanlon \& Heitzman, 2010) or "the international reallocation of profits by an MNC in response to tax differences between countries, with the aim to minimize the global tax bill" (Beer, Mooij \& Liu, 2018)), to stricter definitions such as "anything that causes a firm's cash taxes paid to be different than if the statutory tax rate were applied to pre-tax book income" (Henry $\&$ Sansing, 2014). Finnerty, Merks, Petriccione and Russo (2007) point out that countries accordingly have great difficulty differentiating between international tax planning and tax avoidance, while Beer at al. (2018) in turn refer to the unclear dividing line between tax evasion and tax avoidance.

OECD (2013, p. 5) provides a usable starting point, stating "[t]he interaction of domestic tax systems (including rules adopted in accordance with international standards to relieve double taxation), however, can also lead to gaps that provide opportunities to eliminate or significantly reduce taxation on income in a manner that is inconsistent with the policy objectives of such domestic tax rules and international standards" [emphasis added]. After stating that a universally accepted definition of tax avoidance does not exist, Fuest and Riedel $(2009$, p. 4) provide a more strict interpretation referring to "[t]ax authorities like HMRC [that] define tax avoidance as an activity that a person or a business may undertake to reduce their tax in a way that runs counter to the spirit and the purpose of the law, without being strictly illegal". This definition tallies with the public debate on tax avoidance and the principle behind international political trends such as BEPS. In line with this we assume that there is tax avoidance where tax planning is based on the letter rather than the spirit of the law. Tax avoidance, then, involves contravening the aims of tax legislation.

\subsection{Measuring Tax Avoidance}

In recent years, a substantial strand of literature has accrued on measuring tax avoidance. These studies differ in main objective and the combination of data and research method employed. On the one hand, there are studies concerned with demonstrating or proving the existence of tax avoidance / profit shifting as well as the size of it (see Beer et al., 2018 for a survey of the empirical literature). On the other hand, there is research on the impact of tax avoidance, with a separate strand of literature focused on the impact on developing countries (see e.g., Crivelli, De Mooij \& Keen, 2016; Reynolds \& Wier, 2016; Cobham \& Janský, 2017, 2018a \& 2018b; Dowd, Landefeld \& Moore, 2017; Johannesen, Tørsløv \& Wier, 2017; Bolwijn, Casella \& Rigo, 2018; Bradbury, Hanappi \& Moore, 2018; Janský \& Palanský, 2018; Tørsløv, Wier \& Zucman, 2018).

The research methods for both purposes range from collecting data on stocks and flows related to tax avoidance to econometric analysis (e.g., gravity equations and the elasticity of company profit rates vis-à-vis tax rates). Both countrylevel statistics (or macro-data) and firm-level statistics (or micro-data) are used in these studies. The former often concern Foreign Direct Investment (FDI) flows (e.g., Van 't Riet \& Lejour, 2017; Bolwijn et al., 2018) or foreign affiliates statistics / FATS (e.g., Clausing, 2016; Tørsløv et al., 2018), the latter vary from balance sheet statements (primarily ORBIS data) to corporate tax returns (e.g., Crivelli et al., 2016; Reynolds \& Wier, 2016).

We add to this literature by combining a focus on actual, widely used avoidance structures - based on interest and royalties flows via a conduit country - with firm-level micro-data. Through this approach we are able to show a 'smoking gun' and 
present measurement results beyond econometric estimates. A more precise measurement of avoidance based on specific structures in turn facilitates more effective policy design. Although some studies mention bilateral interest and royalty flows within specific group structures as an accurate method to measure tax avoidance, these same studies point out that firm-level data on these flows is extremely scarce (IHS, CPB \& DONDENA, 2017). To our knowledge, no studies have succeeded in defining and consequently measuring tax avoidance by using firm-level data on flows directly and undisputedly related to avoiding single taxation.

\section{Methodology}

\subsection{A Practical Definition for Calculating Tax Avoidance}

In order to obtain a practical definition that can actually be used to calculate the flows relevant to tax avoidance, we take a step back and look at what could sensibly be interpreted as 'the spirit of the law' and what could not.

Many facilities in international tax law are aimed at preventing double taxation, which means that companies pay taxes over the same flows twice (or even thrice). A simple example will serve to explain this. Say a fictitious internet multinational, Boogle, has a subsidiary, Boogle Junior, in another country. Junior makes a loan to the parent company on which interest is payable. The interest that Boogle Junior receives from its parent company is taxed under corporate tax. If tax (in this case withholding tax) is levied on the interest paid by Boogle in its country of residence, tax is being levied twice on the same interest.

Many countries have introduced specific facilities or have entered into agreements with other countries, for example tax treaties, to prevent this kind of double taxation (Johansson et al., 2017). Let us look again at the simple example given above and relate it to how this could work in practice, taking the actual situation in a conduit country such as the Netherlands. To avoid double payment of tax, the Netherlands does not levy withholding tax on outgoing interest. In the example neither company is Dutch, but in practice a third country such as the Netherlands is often used to prevent double taxation. So it is worthwhile for the multinational to set up a conduit in the Netherlands - provided the Netherlands has a tax treaty with Boogle's parent country that reduces the withholding tax on interest. In that case the subsidiary will make the loan not directly to the parent but to the Dutch conduit, which in turn will loan the money to the parent. Thanks to the tax treaty between the Netherlands and the parent country, the parent company will pay less or no withholding tax on the interest paid to the conduit company in the Netherlands. Furthermore, no withholding tax is levied in the Netherlands on interest paid, so the interest paid by the conduit company to Boogle Junior is not taxed either. By setting up a conduit company in the Netherlands, the tax treaty between the Netherlands and the parent country and the absence of withholding tax in the Netherlands can thus be used to avoid double taxation.

These specific facilities to prevent double taxation can, however, also be used to prevent paying tax at all, referred to as 'double non-taxation'. Let us look again at the example. Whether 'only' double taxation is avoided will depend on how interest is dealt with in the subsidiary's (Junior's) country. Say the corporate tax rate in that country is zero percent: then tax will not be levied anywhere along the financial chain. It cannot be said anymore that merely double taxation is being avoided through the Dutch 'letterbox' company, as no tax at all - or far less ${ }^{3}$ - is being paid.

This line of reasoning provides a more practical definition of acting against the spirit of the law. These tax facilities and treaties are aimed at preventing double taxation; they are obviously not aimed at allowing companies to pay no tax at all. If tax facilities or treaties are used to that end, i.e. to not pay any tax at all, or almost none, they are obviously not in tune with the spirit of the law. We therefore define tax avoidance as the use of constructions aimed at paying no - or almost no - tax in the entire international financial chain.

\subsection{Conceptual Framework}

In order to pay no - or almost no - taxes, financial flows must eventually be taxed in a country where the tax rate is zero or very low, sometimes referred to as 'tax havens' or 'low tax jurisdictions'. ${ }^{4}$ En route to a low tax jurisdiction financial flows will mostly be subject to withholding tax, one way or another, which would prevent double non-taxation. Conduits are used to guide financial flows to low tax jurisdictions while minimizing withholding and other taxes, and are thus vital to achieve the goal of double non-taxation. Constructions using conduits are therefore a logical starting point for

3 The Dutch Tax and Customs Administration requires, based on international principles and article $8 \mathrm{~b}$ of the Dutch Corporate Income Tax Act 1969 (CITA), that there is an arm's length margin between interest received and interest paid.

4 There is no internationally accepted, uniform definition of a 'tax haven'. Based on the OECD-definition dating back to 1998, which still has the most authority, key elements are a low or zero tax rate, prevention of data exchange between countries and low transparency. In this article we will focus on the first element, countries with a low or zero tax rate, referring to them as 'low tax jurisdictions'. 
calculating tax avoidance.

We identify tax avoidance by looking for conduit constructions with the aim of double non-taxation - as opposed to avoiding double taxation. The conceptual framework for estimating the sums involved in tax avoidance is as follows:

1. In the absence of a clear-cut definition we define tax avoidance as MNEs' tax activities that are 'against the spirit of the law'.

2. Assuming that it is not usually the aim of the whole system of tax legislation to enable companies in the international financial chain to pay little or no tax, double non-taxation, in the sense of paying little or no tax, is regarded as possibly acting 'against the spirit of the law'.

3 In order to pay little or no tax, financial flows must eventually be taxed in a low tax jurisdictions.

4. Conduit companies are needed to prevent taxation en route to these low tax jurisdictions. We shall take as our starting point MNEs' flows through conduit companies. We differentiate these as far as possible into (1) flows with the aim of achieving double non-taxation and (2) flows with the aim of avoiding double taxation. As we will see, low tax jurisdictions play a central role in this assessment.

5. We then measure the flows through conduit companies involved in double non-taxation in monetary terms and go on to put forward arguments as to whether it is 'against the spirit of the law'.

This methodology allows us to identify the financial flows via conduit companies that are subject to no or very low taxation within the entire international financial chain. This is not the same as 'missed taxes'. Identifying the tax revenue actually foregone is a complex and virtually impossible exercise, as the whole financial chain needs to be taken into consideration. Assumptions on what the situation would be without a conduit construction - a 'counterfactual' - would be needed on a case-by-case basis, as well as what the rates of withholding tax and corporate tax would be in each case, including relevant tax treaties and other exceptions. Finally, displacement effects would also need to be taken into account.

\subsection{Tax Avoidance Via Conduit Countries in the Netherlands Based on Interest and Royalty Flows}

The way taxes on financial flows are avoided via conduit companies may differ between countries, but the key elements are identical. We will therefore take a specific country, the Netherlands, to apply the methodology for quantifying tax evasion, but it can be applied to other countries as well.

The Netherlands is a well-known conduit country, with attractive tax facilities and treaties with many countries that make it a suitable location for conduit companies (or: SFIs, Special Financial Institutions ${ }^{6}$ ). Although figures to determine the precise relative position of the Netherlands as a conduit country are not available, it is generally considered as one of the main hubs for international tax planning. This is illustrated by the share of Dutch SFIs in total global FDI (excluding the Netherlands), which amounts to $18 \%$ of inward stock and $16 \%$ of outward stock. ${ }^{7}$ In other words, almost one fifth of global inward FDI stock is sourced via Dutch SFIs. This also results in the Netherlands having a strikingly big share in global FDI. When taking FDI via Dutch SFIs into account, the Netherlands is the second biggest country in the world in terms of inward and outward FDI stock, only exceeded by the United States. These figures illustrate the importance of Dutch SFIs in international investment flows in absolute terms, but not their relative role, as data on FDI via SFIs in other conduit countries is not available. Indirect evidence, however, does imply that the Netherlands is one of the main conduit countries, as we illustrate in [authors] based on data from Gravelle (2013) and OECD (2013). In addition, Van 't Riet \& Lejour (2014) use a network approach to identify countries which are most likely to perform the role of conduits. On their main indicator to test the conduit function of countries, The Netherlands ranks fourth. It is thus safe to assume that calculations of tax avoidance via Dutch SFIs amount to a large share of tax avoidance worldwide.

Although there are a host of possible structures for reducing taxes by using conduits, they are usually based on reducing withholding taxes en route to tax havens. This article calculates tax avoidance for two categories of financial flows that

${ }^{5}$ Precisely because it involves paying little or no tax in the whole financial chain within the group, we do not refer here to specific national legislation or regulations but to the legislation in the entire financial chain of financial flows: for example, it could be a question of the law of a source country where a reduction in withholding tax is being claimed wrongfully, or a tax treaty that is being used improperly.

${ }^{6}$ Although in this paper used for one type of company, conduit companies and SFIs are not exactly identical, see section 4.1.

${ }^{7}$ Calculation based on DNB (Statistics on SFIs, table 15.3: http://bit.ly/1TuC6Hh) for FDI via Dutch SFIs and UNCTAD/WIR (2015, p. A7) for total global FDI excluding the Netherlands. Global FDI figures converted from USD to Euro using exchange rates provided by DNB (Exchange rates, year averages, table 2.1: http://bit.ly/117nlPC). In 2005, this share was $13 \%$ and $11 \%$, respectively (Weyzig \& Van Dijk 2007, p. 16). 
are critical for taxes paid by MNEs: interest and royalties.

Under the many tax treaties that the Netherlands has signed, withholding tax on interest paid by foreign companies to Dutch companies is usually reduced. Moreover, in terms of outgoing flows there is no withholding tax on interest paid by Dutch companies to companies abroad. Using these facilities, Dutch SFIs can be used to avoid or substantially reduce withholding tax on interest. Figure 1 illustrates how an MNE can have one of its subsidiaries in a low tax jurisdiction (LTJ) provide a loan to another subsidiary via a Dutch SFI. In this way, no or almost no corporate income tax is paid on interest, by using a low tax jurisdiction, and no - or almost no - withholding tax is paid by using a Dutch SFI.

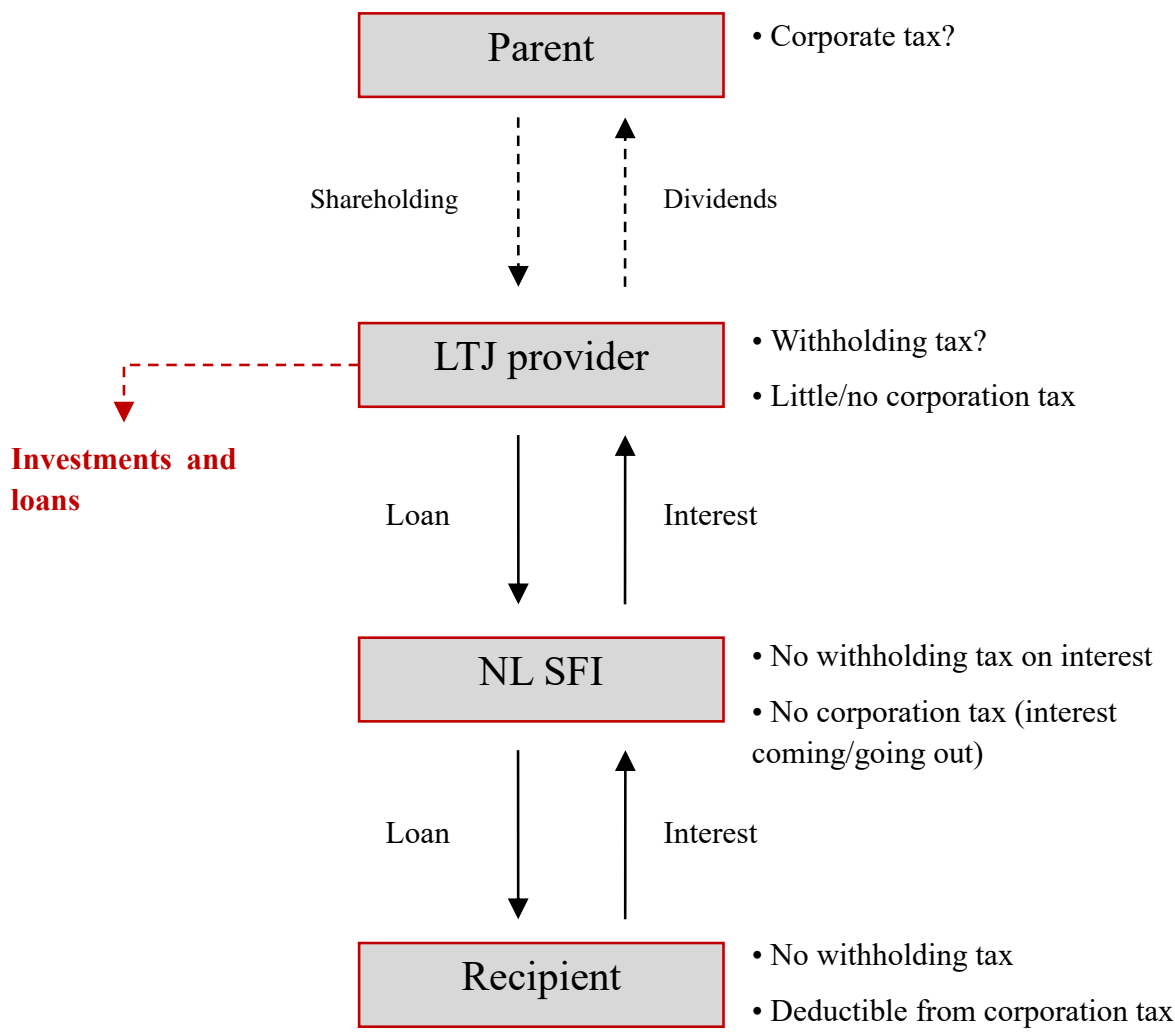

Figure 1. No - or almost no - taxes on interest via Dutch SFIs

Figure 1 further illustrates that there is still a risk of taxation at the end of the financial chain. This is often prevented by not distributing profits as dividends to the parent company, but using them for investments in, or credits to, subsidiaries, as illustrated by the dotted arrow in red.

The above provides a specific criterion by which to determine whether SFIs are being used by an international corporation to pay little or no tax on interest. If an SFI pays interest into a low tax jurisdiction, it is reasonable to assume that the aim is to avoid single taxation: the SFI is then used to pay little or no withholding tax on the interest paid, and little or no corporate tax by paying it into the low tax jurisdiction - resulting in little or no taxes being paid on the interest in the entire international chain (i.e., situation 1 in table 1).

If the country of destination is not a low tax jurisdiction the primary aim is not likely to be to avoid single taxation, as corporate tax will have to be paid on the interest somewhere. Whether the primary aim is to avoid double taxation, is more difficult to gauge. Often there will be some kind of credits (corporate tax can then be offset wholly or partially against withholding tax that has already been paid), so there could be other reasons for using an SFI as a loan intermediary, for example to centralize cash management (i.e. situation $2 b$ in table 1 ).

A third category is when the country of destination is not a low tax jurisdiction, and the countries from which the interest comes and to which it goes are both European Union members. Under the EU directives no withholding tax is levied on interest going from one EU country to another, even without an SFI. In that case the Dutch treaty network and the absence of withholding tax on interest will not offer any advantages, so avoiding double taxation is not likely to be the reason for using an SFI (i.e. situation 2a in table 1). Table 1 summarizes this train of thought. In summary: to calculate the interest flows through SFIs which are not - or almost not - taxed, and thus the flows related to tax avoidance, we have to determine the amount of interest paid by SFIs to group companies in low tax jurisdictions. 
Table 1. Avoiding single taxation when interest goes to low tax jurisdictions

\begin{tabular}{|c|c|c|c|}
\hline \multirow[t]{2}{*}{ If interest goes to... } & \multicolumn{2}{|c|}{...the likely aim is to avoid } & \multirow[t]{2}{*}{ Remarks } \\
\hline & double taxation & single taxation & \\
\hline 1. Low tax jurisdiction & No & Yes & \\
\hline \multicolumn{4}{|l|}{ 2. Other countries: } \\
\hline $\begin{array}{l}\text { 2a. Interest to and from EU } \\
\text { countries }\end{array}$ & No & No & $\begin{array}{l}\text { The Dutch treaty network does not offer } \\
\text { any advantages; the reasons are } \\
\text { primarily non-tax-driven. }\end{array}$ \\
\hline
\end{tabular}

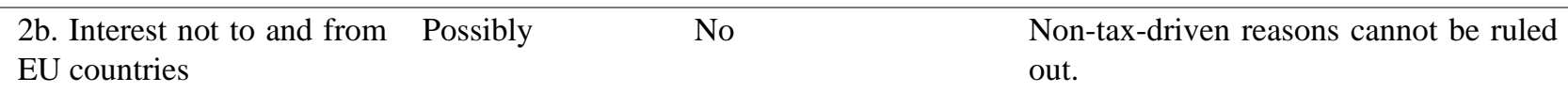

The situation with royalties is similar to that regarding interest, replacing 'loan' in figure 1 with 'trademark licence' and 'interest' with 'royalties'. Unlike with loans, the issue with licences tends to be transfer pricing. In the case of loans and the interest on them it is possible to set market prices; this is far more difficult in the case of licences and royalties. Royalty constructions transfer trademark rights and patents to low tax jurisdictions. Group companies in other countries then pay a fee - a royalty - to the company in the low tax jurisdiction for the use of the trademark. Royalties are usually taxdeductible in the country paying them and are not taxed, or taxed at a low rate, in the low tax jurisdiction.

Notwithstanding the specific issues, in the same way as with interest, a Dutch SFI can avoid or reduce withholding tax on royalties paid by using the Dutch treaty network and the fact that there is no withholding tax on royalties paid from the Netherlands to foreign companies. And, again similar to interest, to calculate the royalty flows through SFIs which are not - or almost not - taxed, and thus the flows related to tax avoidance, the amount of royalty paid by SFIs to group companies in low tax jurisdictions must be determined.

3.4 What is Paying 'Almost no Taxes'?

A question that needs to be answered before we can calculate tax avoidance is when a country should be regarded as a tax haven or low tax jurisdiction. As explained above, double non-taxation (i.e., acting 'against the spirit of the law') is possible if the country to which a SFI pays interest or royalties has a zero or very low corporate tax rate. The question here is what should be regarded as 'very low'. This question has a moral dimension, as the answer will reflect what amount of tax paid is regarded as 'enough' or 'fair'. A zero rate will obviously be regarded as too low, while a rate of $35 \%$ will probably not. But can $5 \%$ be regarded as enough, or $10 \%$ or $12.5 \%$ ? The Dutch government implicitly sets the lower limit at $10 \%$ as part of the participation exemption, ${ }^{8}$ but this is certainly not set in stone in the international discussion on paying a fair share of taxes. We therefore calculate tax avoidance based on three definitions of low tax jurisdictions:

1. Countries with nominal corporate tax of $10 \%$ of lower

2. Countries with nominal corporate tax of $15 \%$ or lower

3. Tax havens according to the list by Jane Gravelle, reflecting the common denominator in various tax haven lists.

These options, in other words, help operationalize the concept of acting 'against the spirit of the law'. A definition of low tax jurisdictions based on a tax rate of $10 \%$ or lower can be seen as stricter, while using a tax haven list results in a broader, less strict definition, thereby reflecting a different moral point of view as to what is a fair tax rate. These three different definitions provide a bandwidth within which the amounts of flows related to tax avoidance are most likely to fall.

Given the availability of data we use nominal tax rates instead of effective tax rates. A disadvantage of using nominal tax rates, however, is that the effective tax rate may be lower, hence tax avoidance may be underestimated. On the other hand, a disadvantage of using a tax haven list is that it will include countries with a 'normal' tax rate, based purely on e.g. lack of transparency, hence tax avoidance may be overestimated.

\section{Empirical Results}

4.1 Data

The Dutch Central Bank, De Nederlandsche Bank (DNB), collects data on 'special financial institutions' (SFIs), which it defines as Dutch-based companies owned directly or indirectly by foreign companies, whose activities primarily consist in attracting funds from outside the Netherlands and lending or investing these funds outside the Netherlands. An important reason for their existence, and why they are based in the Netherlands, is reducing tax payments. By using SFIs,

${ }^{8}$ Under the participation exemption dividends received from a subsidiary (domestic or foreign) are not included in the corporate tax base in the Netherlands if certain circumstances are met. 
MNEs enjoy tax advantages in the Netherlands or in other countries where group companies are located. Based on this definition SFIs closely resemble conduit companies, although the scope of their activities may be broader than tax avoidance alone. ${ }^{9}$ SFIs - also called letterbox or mailbox companies - thus provide a good starting point for calculating tax avoidance, with the additional advantage that data for calculations is available via the Dutch Central Bank.

Data on SFIs are collected by DNB as part of its statistical responsibility for determining the Dutch balance of payment and international investment position. These reporting requirements are laid down in the Balance of Payment Manual of the International Monetary Fund (IMF). SFIs report these data to DNB directly via monthly, annual and biennial reporting forms. ${ }^{10}$ These company-level data (or micro-data) were anonymized and made available for this study through the Dutch statistical agency, Statistics Netherlands (subsequently referred to as 'CBS'). DNB and CBS have checked all the output for risk of disclosure: tables and graphs must be sufficiently 'aggregated' so as not to disclose data on individual companies. Output that did not meet the anti-disclosure requirements ${ }^{11}$ was not 'cleared' for publication by DNB and CBS and is indicated as 'N/A' (not available) in tables and graphs.

Data on all Dutch SFIs is collected once every two years, 2012 being the most recent year available to us Stocks (e.g. balance sheet items) and flows (i.e. dividends, interest and royalties) on country level, which is needed for the calculation of flows related to tax avoidance, are available only for the cut-off sample of the approximately 2,000 largest Dutch SFIs for the 2006-2013 period (2013 being the most recent year available). ${ }^{12}$ These largest SFIs account for around $15 \%$ of all SFIs and around $90 \%$ of the balance sheet total of all Dutch SFIs and as such have more frequent and more detailed reporting obligations, including country breakdowns of their stocks and flows. In other words, the data presented on tax avoidance in this article are representative of the entire Dutch SFI population, albeit not comprehensive. The data are not weighted (i.e. incremented) to represent all Dutch SFIs, since there is no apparent or validated relationship between balance sheet total and tax avoidance. In other words, it is not empirically evident that the $90 \%$ largest SFIs in terms of balance sheet total are also responsible for $90 \%$ of flows related to tax avoidance.

\subsection{Descriptive Statistics}

In 2012, there were roughly 12,000 special financial institutions in the Netherlands, with a collective balance sheet total of 3,300 billion euro (table 2). The collective balance sheet total increased by $80 \%$ in the last 6 years, while the number of SFIs rose by $35 \%$ (figure 2). This indicates that the average size of SFIs has grown, from an average balance sheet total of 200 million euro in 2006 to 270 million euro in 2012. Furthermore, there is a trend towards consolidation of SFIs belonging to the same corporate group. Roughly $50 \%$ of all SFIs is part of a so-called 'cluster' of multiple SFIs belonging to the same corporate group. The other 50\% are standalone SFIs. In 2006, this ratio was 30\% clustered SFIs versus $70 \%$ standalone SFIs. Also, the average number of SFIs per cluster has grown steadily, from 2.7 in 2006 to 3.6 in 2012 . The total amount of incoming and outgoing royalties, dividends and interest was approximately 140 billion euro in 2012 (figure 3).

9 According to the Dutch Central Bank, the Dutch concept of SFI is in line with the OECD concept of 'Special Purpose Entity' (DNB, 2008). See for instance Baarsma et al. (2014) and Weyzig (2007) for a detailed analysis of SFIs and tax avoidance via SFIs. The Dutch Central Bank provides a detailed description of financial versus non-financial SFIs in FSB (2012, Annex 5).

10 These reporting forms follow statistical definitions of economic concepts (prescribed inter alia by the IMF, ECB and Eurostat), which can differ from their definitions in financial accounting and reporting standards (e.g. IFRS and NL GAAP).

${ }^{11}$ In short, there are two requirements: (1) reported figures must relate to at least 10 SFIs; (2) the share of the largest SFI in the reported figure (e.g. the largest flow attributable to one SFI) must not exceed 55\%. If one or both of these requirements is/are not met, there is a disclosure risk and the data cannot be published. It also follows that if there is a disclosure risk in a breakdown, at least two figures must be blacked out, so that redacted values cannot be traced back from row or column totals.

12 The figures that SFIs report to DNB are not 'final' in statistical terms: SFIs are allowed to 'backwardly correct' previously provided data, for instance if they fill in preliminary data which they later on adjust as a result of the then published annual report for that fiscal year. 
Table 2. More SFIs and higher balance sheet total

\begin{tabular}{llll}
\hline & Number of SFIs & Balance sheet total $($ bn $€)$ & Average balance sheet total $(\mathrm{m} €)$ \\
\hline 2006 & 9,142 & 1,843 & 202 \\
\hline 2008 & 10,993 & 2,505 & 228 \\
\hline 2010 & 12,010 & 2,863 & 238 \\
\hline 2012 & 12,228 & 3,304 & 270 \\
\hline
\end{tabular}

Note: Based on all SFIs.

Growth indices $(2006=100)$

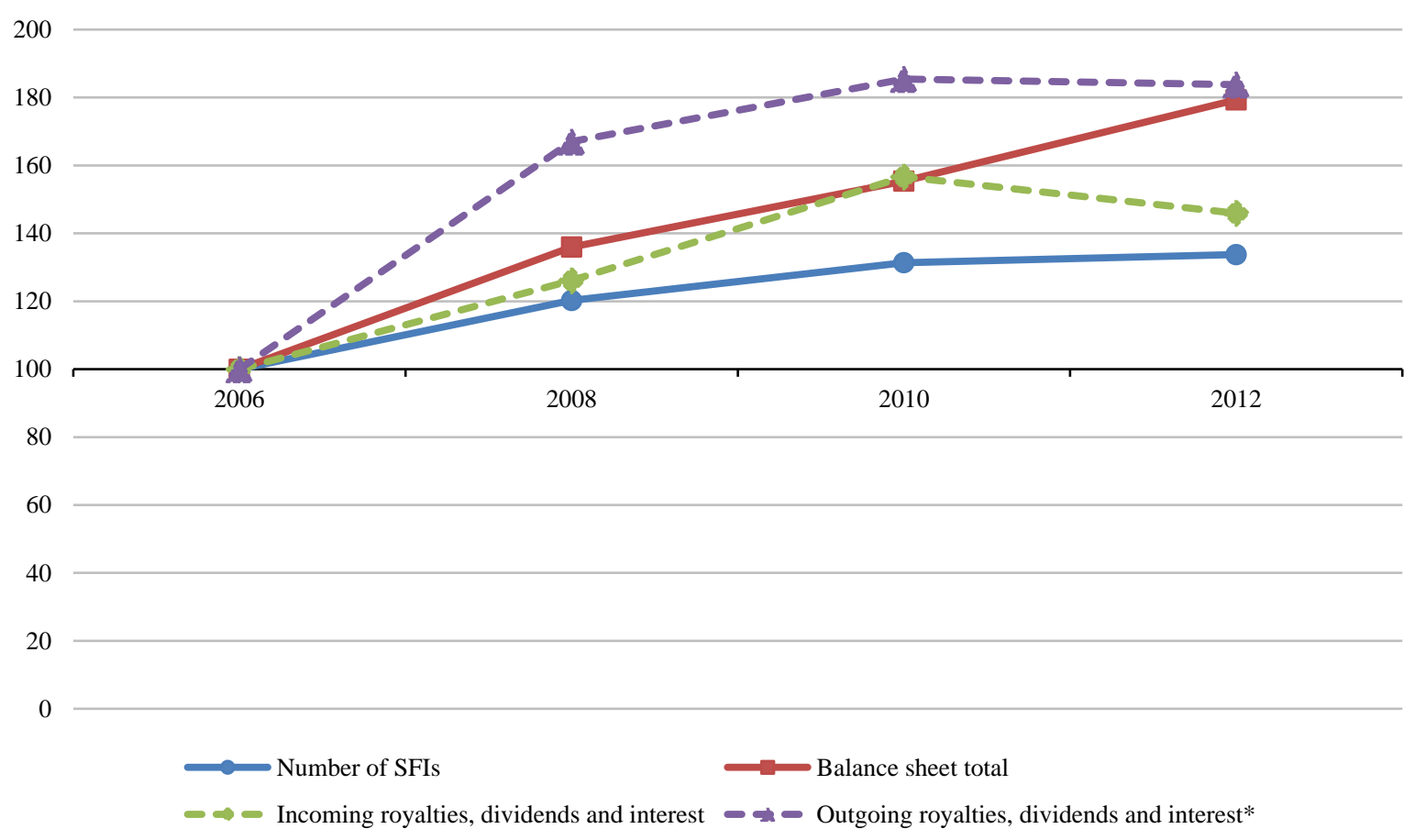

Figure 2. Dutch SFI sector has been growing rapidly in the last 6 years

Note: Based on all SFIs, gross flows. * Excluding outgoing royalties in 2012 due to disclosure risk.

Incoming flows (bn $€)$

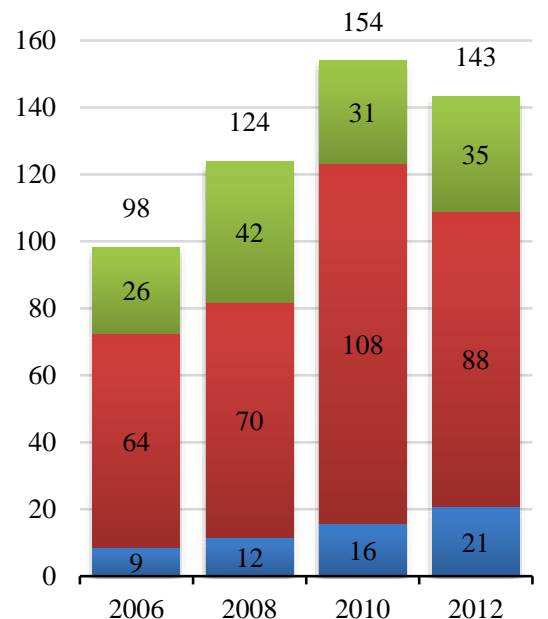

Outgoing flows (bn €)

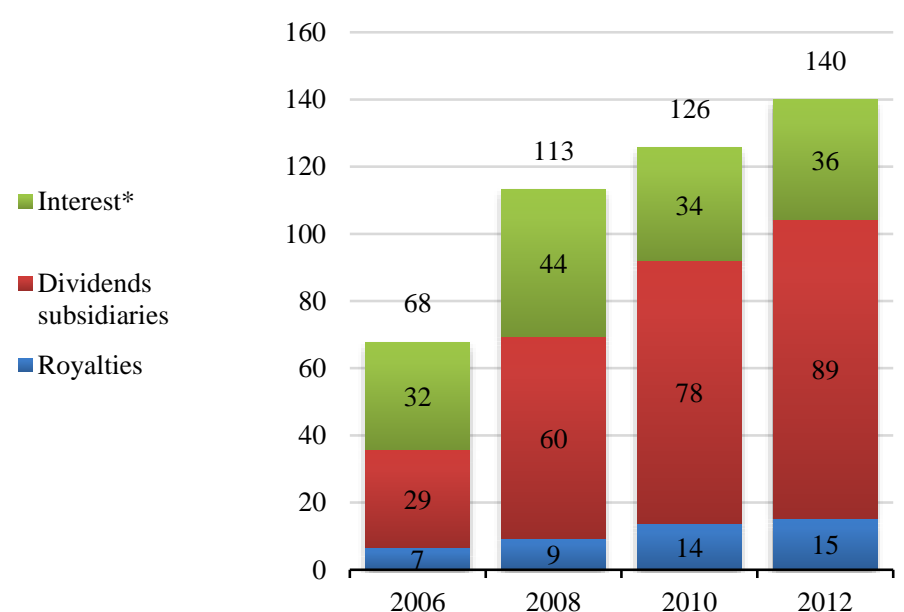

Figure 3. Overall increase in incoming and outgoing flows 
Note: Based on all SFIs, gross flows. * Interest flows include dividends on shares (i.e. not dividends from subsidiary/daughter companies) since small SFIs report interest and dividends on stocks as one flow.

The calculations of flows related to tax avoidance are based on the sample of largest SFIs in the Netherlands, since only they are obligated to provide country breakdowns of their stocks and flows. As was mentioned previously, these SFIs account for around $15 \%$ of all SFIs and for around $90 \%$ of the balance sheet total of all Dutch SFIs. In terms of fiscally relevant incoming and outgoing flows they are responsible for close to $85 \%$ of the total flows, indicating that they are highly representative for the total Dutch SFI population (figure 4).

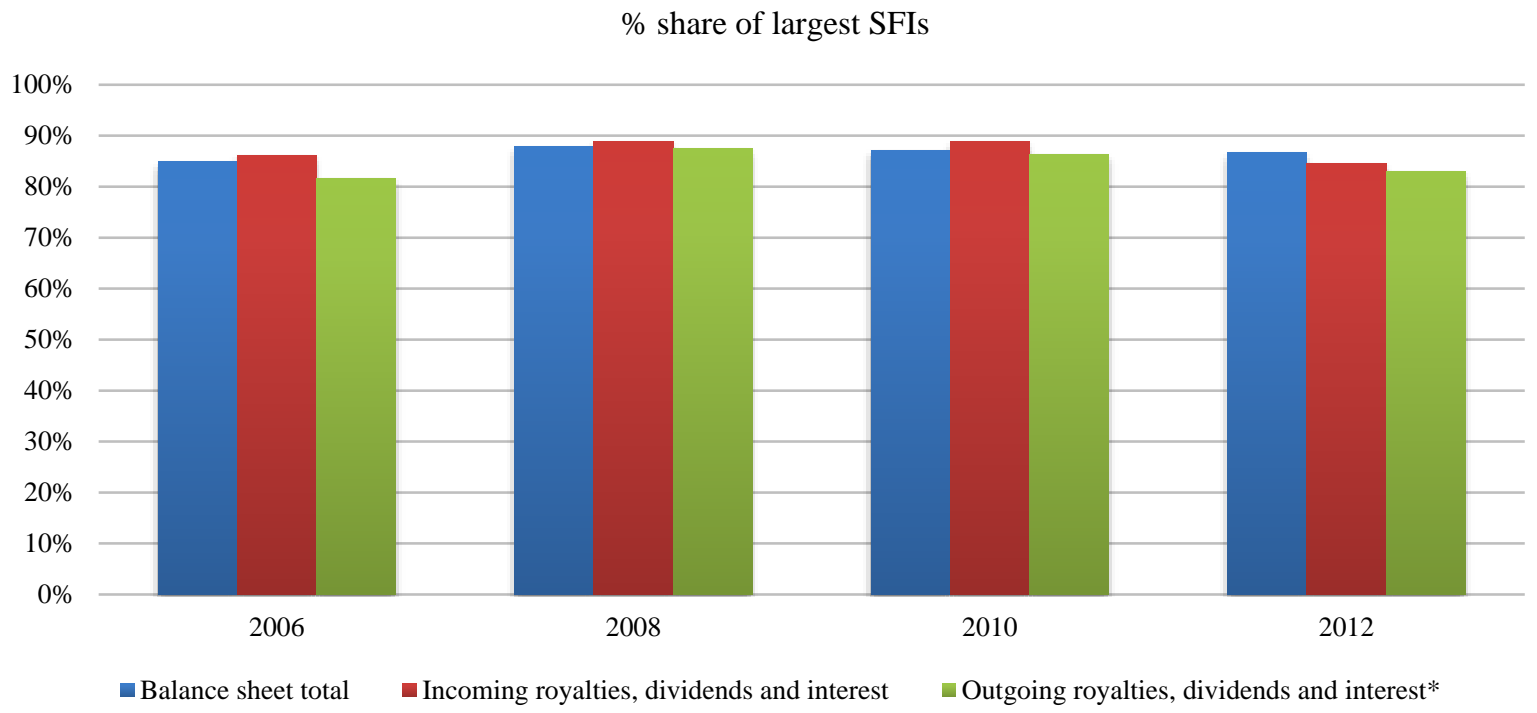

Figure 4. Largest SFIs make up for 80 to $90 \%$ of balance sheet total and fiscally relevant flows

Note: Based on all SFIs, gross flows. * Excluding outgoing royalties in 2012 due to disclosure risk.

4.3 Results

To calculate the flows related to tax avoidance, we determine the amount of interest and royalty paid by SFIs to group companies in low tax jurisdictions. Table 3 indicates that the total flow of interest related to tax avoidance was around 1.1 billion to 2.6 billion euro in 2013, depending on the definition of a 'low tax jurisdiction': countries with corporate tax less than $10 \%$ or less than $15 \%$, respectively. These flows were somewhat volatile in the period 2009-2013, as indicated by the higher 5 year average of 1.4 billion and 2.7 billion euro, respectively. If all tax havens on Gravelle's list are taken into consideration, the interest flow related to tax evasion accrues to 3.6 billion euro in 2013. In 2013, there were 58 SFIs that reported outgoing intragroup interest flows to low tax jurisdictions ' $10 \%$ ' and 115 SFIs if low tax jurisdictions with corporate tax between 10 and $15 \%$ are also taken into account.

The outgoing royalty flows to low tax jurisdictions cannot be reported for 2013, since they are dominated by a few large SFIs, which would make the results deducible to individual SFIs. In fact, these royalty flows are accounted for by less than 10 SFIs considering low tax jurisdictions ' $10 \%$ ', and exactly 10 SFIs considering low tax jurisdictions ' $15 \%$ '. ${ }^{13}$ When accumulating annual royalty flows of multiple years, SFIs dominating royalty flows is no longer an issue, which facilitates providing insight in the relevant royalty flows over 2009-2013. The total outgoing royalty flows to low tax jurisdictions '10\%' between 2009 and 2013 amounted to 41.6 billion euro, an annual average of 8.3 billion euro. Broadening the scope to low tax jurisdictions ' $15 \%$ ' increases this yearly average to 9.2 billion euro. Royalty flows to all tax havens on Gravelle's list cannot be reported, in view of domination by a few large SFIs.

${ }^{13}$ It cannot be ruled out that there are small SFIs outside the cut-off sample of largest SFIs that also have outgoing interest and/or royalty flows to low tax jurisdictions. This cannot be verified since these SFIs are not required to provide country breakdowns of their flows. 
Table 3. Flows through SFIs with the aim of paying little or no tax

\begin{tabular}{lll}
\hline Perspective on low tax jurisdictions & Outgoing royalties & Outgoing interest on intragroup loans \\
\hline Corporate tax $<10 \%$ & N/A $(8,314)$ & $1,080(1,369)$ \\
\hline Corporate tax $<15 \%$ & N/A $(9,161)$ & $2,565(2,715)$ \\
\hline Tax havens (Gravelle) & N/A (N/A) & $3,603(3,916)$
\end{tabular}

Note: Based on the largest SFIs, amounts x 1 million euro, gross flows, 2013 and (between brackets) average 2009-2013.

To provide insight in which countries are used as tax havens in avoidance structures, figure 5 illustrates which low tax jurisdictions are the most important in term of their share of the outgoing flows. Bermuda accounted for the largest share of outgoing royalties and outgoing interest on intragroup loans in the period 2009-2013. ${ }^{14}$ Other important low tax jurisdictions are the Cayman Islands (second place after Bermuda for royalties and interest), the United Arab Emirates, Jersey, Guernsey and the British Virgin Islands.

Top-10* most important low tax jurisdictions $<10 \%(2009-2013)$

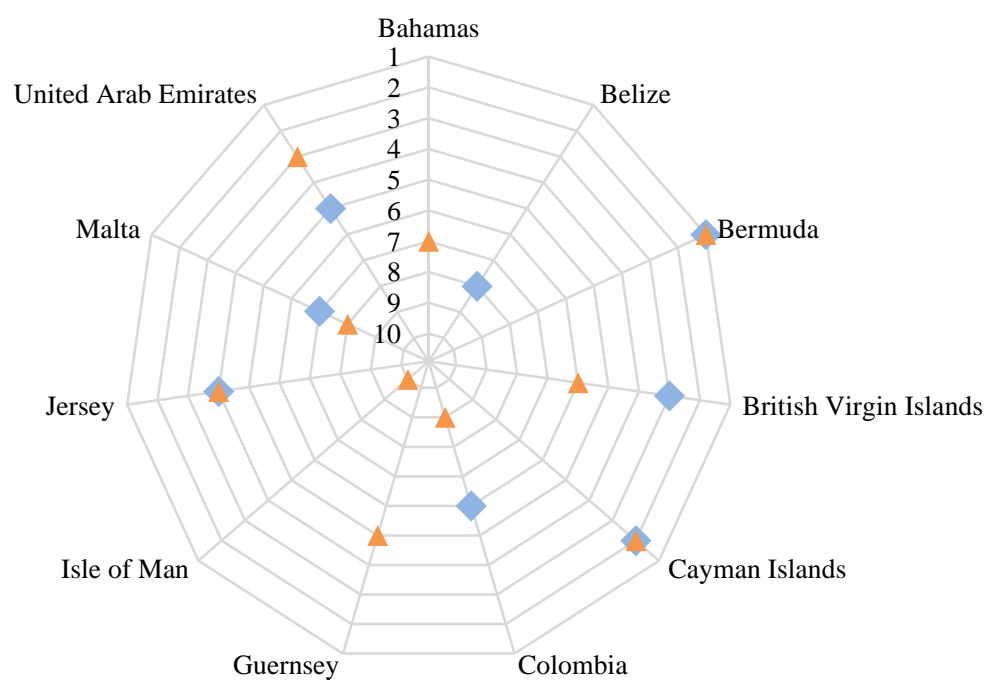

$\diamond$ Outgoing royalties $\Delta$ Outgoing interest on intragroup loans

Figure 5. Ranking of low tax jurisdictions below $10 \%$

Note: By proportion of flows related to tax avoidance, from 1 (country where SFIs report largest flow) to 10 (based on the largest SFIs, gross flows, averages for 2009-2013). * SFIs reported outgoing royalty flows to 8 low tax jurisdictions in the period 2009-2013. That is why for outgoing royalties a top-8 rather than a top-10 is presented.

\section{Discussion and Limitations}

The calculations in this paper shed light on the magnitude of the problem of tax avoidance. We apply our methodology to provide an indication of the flows related to tax avoidance via conduit companies and the use of low tax jurisdictions. We do this for one country, the Netherlands, and for two types of financial flows, interest and royalties. Although our calculations are limited to one country and two types of financial flows, the Netherlands can be regarded as one of the bigger conduit countries and the types of flows as two of the more important ones. It is important to note that a relatively small proportion of conduit companies in the Netherlands are responsible for tax avoidance: 58 to 115 of the 2,000 largest SFIs in 2013 when looking at interest flows and no more than 10 when looking at royalty flows. It should be noted that companies have more possibilities to avoid taxes then via the use of conduit companies and low tax jurisdictions, e.g. via hybrid mismatches, division of profits between countries and certain forms of transfer pricing. This means that the total,

${ }^{14}$ Bermuda also accounts for the largest share of incoming dividends from low tax jurisdictions (see 'Discussion', in section 5). 
global financial flows related to tax avoidance will evidently be higher. ${ }^{15}$ More research is needed to gain insight in other forms of tax avoidance, although limited data availability poses a challenge in this regard.

Although this is possible with data from the Dutch Central Bank, we have not provided results for a third important type of financial flows, namely dividends. To calculate tax avoidance based on dividend flows via conduit companies in the Netherlands in line with the approach in this paper, we have to look at dividend flows from low tax jurisdictions to SFIs rather than flows from SFIs to low tax jurisdictions, as is the case with interest and royalties, After all, corporate tax is levied on the profit in the country the dividend originates from. Apart from that the same methodology can be used. Our calculations show that these amounts are substantially higher than for interest payments: on average 4.5 billion euro or 18.3 billion euro per year from countries with corporate tax less than $10 \%$ or less than $15 \%$, respectively, both for the period 2009-2013. However, in discussions with tax consultants and government officials in the Netherlands a difference of opinion emerged on tax avoidance based on dividend payments. Dutch tax law explicitly allows a zero tax rate in a country from which dividends are received as long as the underlying activities are 'real', i.e. the subsidiary in the low tax jurisdiction is 'active' rather than 'passive'. In other words, although the situation in which an SFI receives dividends from a zero-rate tax jurisdiction could be regarded as double non-taxation, it is not against the spirit of the Dutch law as long as the activities are real. Data from the Dutch Central Bank does not distinguish between dividends received from active or passive subsidiaries. As such, it is not possible to determine with certainty whether conduit companies are acting against the spirit of the law when they receive dividends from low tax jurisdictions. Data does show from which countries SFIs receive dividends. Based on the fact that Bermuda, Guernsey and Jersey are the low tax jurisdictions '10\%' from which SFIs received the most dividend between 2009 and 2013, it seems likely that at least some of these flows are related to tax avoidance.

A final limitation of our paper is that writing on tax avoidance will always have a moral dimension. We have deliberately avoided making a moral judgement by including three calculations for different moral points of view on what constitutes 'sufficient taxes'. It is up to reader to pass his or her own judgement and choose the calculations that accord with his or her moral views. Whether the amount of flows is regarded as high or not also needs to be assessed within a political context. Many tax laws and regulations exist because governments want to facilitate international trade and avoid double taxation for MNEs. Tax avoidance may, therefore, fit with carefully considered government policy.

\section{Conclusion and Policy Implications}

This article provides a definition of tax avoidance that facilitates pinpointing SFIs and calculating financial flows related to tax avoidance, as well as a methodology for actually calculating these flows. Using this methodology, we calculate financial flows related to tax avoidance via conduit companies in the Netherlands based on interest and royalty income. For interest, these financial flows amount to 1.4 billion or 2.7 billion euro on average per year in 2009-2013, when defining low tax jurisdictions as countries with corporate tax less than $10 \%$ or less than $15 \%$ respectively. For royalties, these flows amount to 8.3 billion or 9.2 billion euro, respectively. On average, this a total of 9.7 or 11.9 billion euro outgoing royalty and interest flows per year.

Conduit countries are a key step in tax avoidance constructions, as they facilitate channelling financial flows to low tax jurisdictions. But the underlying tax facilities and treaties are not primarily aimed at tax avoidance - they are aimed at preventing double taxation. In other words, tax avoidance can be seen as 'collateral damage'. As such, prohibiting these tax facilities and treaties is not the best solution, as it could result in double taxation and thus impede international trade. Moreover, it would be too simple to put the blame on the conduit countries: other countries in the financial chain have equal responsibility for assessing whether constructions taking advantage of treaties signed by them, or more generally that have an impact on their tax base, are in the spirit of the law. Indeed, in the case of interest and royalties it is technically the host country that is responsible for identifying and challenging conduit constructions. This points to the importance of international cooperation in fighting undesirable tax avoidance, as well as the need for transparency. If a country such as the Netherlands were to abolish its tax facilities, multinationals would move to the UK, Luxembourg or some other conduit country. Unilateral actions will generally be a case of political symbolism rather than actually changing the situation globally. International exchange of information is also vital if we are to be sure that the right constructions are being tackled: there needs to be a requirement for tax authorities to be aware of one another's fiscal rulings, for example.

In addition, data on conduit companies and their financial flows is a sine qua non for detailed calculations of tax avoidance. Initial examination of the international data - provided by, for instance, central banks - as part of our earlier research points to a blind spot in this regard in many other countries. For a proper assessment of proposed regulation going forward,

15 A more technical source of underestimation is the fact that the available data provide insight into the next link in the financial chain only. If the next link in the chain is not a low tax jurisdiction but the flow is ultimately forwarded to a low tax jurisdiction, this flow is also related to tax avoidance. This, however, cannot be determined. 
it is essential that these data requirements are included in the international discussion on transparency.

When it comes to discussing tax avoidance the absence of clear definitions is problematic. When is avoiding single taxation 'in the spirit of the law' and when is it not? When and if a company is actually acting 'against the spirit of the law', hence when and if there is tax avoidance, is ultimately a political judgment. The absence of any explicit political dividing line between tax planning and tax avoidance creates a grey area. Setting clear limits, then, is the first thing that is needed to tackle tax avoidance. This paper provided input for the Dutch ministry of Finance to set such limits.

Our paper shows that in order to prevent international tax systems from being used for double non-taxation, governments could introduce a withholding tax on outgoing interest and royalty flows to low tax jurisdictions (tax havens). First of all, the paper shows the importance of tax havens, specifically low tax jurisdictions, in achieving double-non-taxation. While many countries see tax rates as a sovereign, domestic affair, facilities in other countries - such as tax treaties or the absence of withholding tax on outgoing interest or royalties - are mostly needed to take advantage of the low rates in tax havens without having to pay taxes en route to the tax haven. Notwithstanding the sovereign right of countries to set tax rates, facilities in other countries could be made dependent on a minimum tax rate being paid in the entire financial chain. Secondly, this paper shows the cost of not doing this: the possibility of tax avoidance on large financial flows. In 2018 the Dutch Ministry of Finance decided to adjust the tax policy in line with our results. To prevent the internationally oriented Dutch tax system from being used for transfer activities to tax havens, the Dutch government will introduce a withholding tax on outgoing interest and royalty flows to low tax jurisdictions as of 2021. According to the Dutch government low tax jurisdiction means countries with a low statutory rate (i.e., less than $9 \%$ ) or countries included on the EU list of non-cooperative countries.

\section{Acknowledgement}

The authors declare that they have no conflict of interest. All authors were working at SEO Amsterdam Economics at the time of writing this article (Roetersstraat 29, 1018 Amsterdam, the Netherlands). This research was financed by SEO Amsterdam Economics, and did not receive any specific grant from funding agencies in the public, commercial, or notfor-profit sectors. It builds partly on earlier work by the authors, which was also funded by SEO Amsterdam Economics.

\section{References}

[dataset] DNB. Exchange rates. http://bit.ly/117nlPC (accessed July 16 2015).

[dataset] DNB. Statistics on SFIs. http://bit.ly/1TuC6Hh (accessed December 2 2015).

Baarsma, B., Kerste, M., \& Weda, J. (2014). Brievenbusmaatschappijen - De impact van bijzondere financiële instellingen op de Nederlandse economie [Letterbox companies - The impact of special financial institutions on the Dutch economy]. Antwerp: Business Contact.

Beer, S., Mooij, de R., \& Liu, L. (2018). International Corporate Tax Avoidance: A Review of the Channels, Effect Sizes, and Blind Spots. IMF Working Paper, WP/18/168. https://doi.org/10.5089/9781484363997.001

Birks, J. (2017). Tax avoidance as an anti-austerity issue: The progress of a protest issue through the public sphere. European Journal of Communication, 32(4), 296-311. https://doi.org/10.1177/0267323117710898

Bolwijn, R., Casella, B., \& Rigo, D. (2018). An FDI-driven approach to measuring the scale and economic impact of BEPS. Transnational Corporations, 25(2), 107-143. https://doi.org/10.18356/c4f9fd3c-en

Bradbury, D., Hanappi, T., \& Moore, A. (2018). Estimating the fiscal effects of base erosion and profit shifting: data availability and analytical issues. Transnational Corporations, 25(2), 91-106. https://doi.org/10.18356/e1d7a8b4-en

Clausing, K. A. (2016). The effect of profit shifting on the corporate tax base in the United States and beyond. National Tax Journal, 69(4), 905-934. https://doi.org/10.17310/ntj.2016.4.09

Cobham, A., \& Janský, P. (2017). Measuring misalignment: the location of US multinationals' economic activity versus the location of their profits. Development Policy Review. https://doi.org/10.1111/dpr.12315

Cobham, A., \& Janský, P. (2018a). Global distribution of revenue loss from tax avoidance: re-estimation and country results. Journal of International Development, 30, 206-232. https://doi.org/10.1002/jid.3348

Cobham, A., \& Janský, P. (2018b). Measurement of Illicit Financial Flows. Background paper prepared for UNCTAD.

Crivelli, E., Mooij de R., \& Keen, M. (2016). Base Erosion, Profit Shifting and Developing Countries. Public Finance Analysis, 72(3), 268-301. https://doi.org/10.1628/001522116X14646834385460

DNB (2008). Nederland nog steeds aantrekkelijk voor bfi's [The Netherlands: still attractive to SFIs], In Statistisch Bulletin, September, 21-24. 
Dowd, T., Landefeld, P., \& Moore, A. (2017). Profit shifting of U.S. multinationals. Journal of Public Economics, 148, 1-13. https://doi.org/10.1016/j.jpubeco.2017.02.005

Finnerty, C., Merks, P., Petriccione, M., \& Russo, R. (2007). Fundamentals of International Tax Planning. Amsterdam: IBFD Publications BV.

FSB (2012). Global Shadow Banking Monitoring Report 2012. Basel: Financial Stability Board.

Fuest, C., \& Riedel, N. (2009). Tax evasion, tax avoidance and tax expenditures in developing countries: A review of the literature. Report prepared for the UK department for International Development. Oxford: Oxford University Centre for Business Taxation.

Gravelle, J. G. (2013). Tax Havens: International Tax Avoidance and Evasion. Washington, DC: Congressional Research Service, 23/01.

Gumpert, A., Hines, J. R., J., \& Schnitzer, M. (2016). Multinational Firms and Tax Havens. The Review of Economics and Statistics, 98(4), 713-27. https://doi.org/10.1162/REST_a_00591

Hanlon, M., \& Heitzman, S. (2010). A review of tax research. Journal of Accounting and Economics, 50(2-3), 127-178. https://doi.org/10.1016/j.jacceco.2010.09.002

Heckemeyer, J. H., \& Overesch, M. (2017). Multinationals' Profit Response to Tax Differentials: Effect Size and Shifting Channels. Canadian Journal of Economics, 50(4), 965-994. https://doi.org/10.1111/caje.12283

Henry, E., \& Sansing, R. C. (2014). Data Truncation Bias and the Mismeasurement of Corporate Tax Avoidance. 2014 American Taxation Association Midyear Meeting, September 29, 2014. Available at SSRN: http://ssrn.com/abstract=2329694 (accessed July 15 2015).

Henry, J. S. (2012). The price of offshore revisited. Chesham. Bucks UK: Tax Justice Network.

IHS, CPB \& DONDENA (2017). Aggressive tax planning indicators: Final Report. Working Paper No 71 - 2017. Brussels: European Commission.

Janský, P., \& Palanský, M. (2018). Estimating the scale of profit shifting and tax revenue losses related to foreign direct investment, WIDER Working Paper 2018/21. Helsinki: UNU-WIDER.

Johannesen, N., Tørsløv, T., \& Wier L. (2017). Are less developed countries more exposed to multinational tax avoidance? Method and evidence from micro-data. WIDER Working Paper 2016/10, revised version May 2017. Helsinki: UNUWIDER.OECD (2015a). OECD/G20 base erosion and profit shifting project: explanatory statement. Paris: Organisation for Economic Cooperation and Development.

Johansson, Å., Bieltvedt, S. Ø., Sorbe, S., \& Menon, C. (2017). Tax planning by multinational firms: Firm-level evidence from a cross-country database. OECD Economics Department Working Papers, No. 1355. Paris: OECD Publishing. https://doi.org/10.1787/9ea89b4d-en.

Kar, D., \& Freitas, S. (2012). Illicit Financial Flows from Developing Countries: 2001-2010. Washington, DC: Global Financial Integrity. https://doi.org/10.2139/ssrn.2335028

Murphy, R. (2012). Closing the European Tax Gap: A report for Group of the Progressive Alliance of Socialists \& Democrats in the European Parliament. Norfolk UK: Tax Research LLP.

OECD (2013). Addressing Base Erosion and Profit Shifting. Paris: OECD Publishing.

OECD (2015b). Glossary of Tax Terms. Available at OECD: http://www.oecd.org/ctp/glossaryoftaxterms.htm (accessed July 15 2015).

Reynolds, H., \& Wier, L. (2016). Estimating profit shifting in South Africa using firm-level tax returns. WIDER Working Paper Series 128, World Institute for Development Economic Research (UNU-WIDER).

Spengel, C., Heckemeyer, J. H., Nusser, H., Klar, O., \& Streif, F. (2016). The Impact of Tax Planning on Forward-Looking Effective Tax Rates, Taxation Paper Series no. 64, Brussels: European Commission.

Tørsløv, T. R., Wier, L. S. , \& Zucman, G. (2018). The Missing Profits of Nations. Working Paper No. 24701. National Bureau of Economic Research. https://doi.org/10.3386/ w24701.

UNCTAD/WIR (2015). World Investment Report 2015: Reforming International Investment Governance. Geneva: United Nations Conference on Trade and Development.

Van 't Riet, M,. \& Lejour, A. (2014). Ranking the Stars: Network Analysis of Bilateral Tax Treaties. CPB Discussion Paper No. 290. The Hague: CPB Netherlands Bureau for Economic Policy Analysis.

Van 't Riet, M., \& Lejour A. (2018). Optimal Tax Routing: Network Analysis of FDI diversion, International Tax and 
Public Finance, 25(5), 1321-1371. https://doi.org/10.1007/s10797-018-9491-6

Weyzig, F. (2007). The central role of Dutch financing companies in tax avoidance strategies. Amsterdam: Vrije Universiteit. (master thesis).

Weyzig, F., \& Van-Dijk, M. (2007). Tax Haven and Development Partner: Incoherence in Dutch Government Policies? Amsterdam: SOMO. https://doi.org/10.2139/ssrn.1660429

\section{Copyrights}

Copyright for this article is retained by the author(s), with first publication rights granted to the journal.

This is an open-access article distributed under the terms and conditions of the Creative Commons Attribution License which permits unrestricted use, distribution, and reproduction in any medium, provided the original work is properly cited. 